THE "NELATON" PATENT VALVE SYRINGE TUBE.

Tris syringe tube has been introduced to supersede those generally in use on account of two special features. First of all it is perfectly flexible; then, instead of the usual aperture, it has several fine slits which open out when fluid is forced into the tube, but are quite closed and almost imperceptible at other times. The flexibility of such a tube

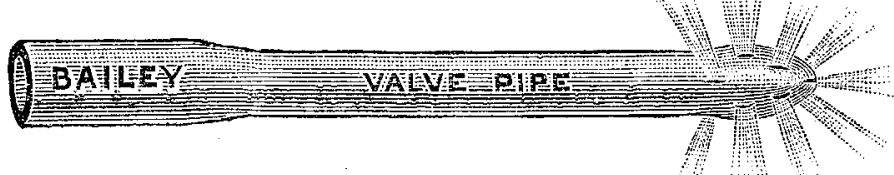

is a matter of the very highest importance; the number of accidents that have occurred, even to trained nurses, from the use of ivory and other rigid enema tubes is so large that they ought to be universally abandoned. It is also well known that unless great care is taken in its manufacture, the common large aperture in a rubber tube may be a cause of a great deal of pain to the patient. This cannot arise when such a tube as the "Nelaton" is used.

\section{NEW UTERINE SUPPORT FOR EQUESTRIENNES.}

SHortur after my association with the Wild West I asked the frontier girls whether the violent riding did not shake them considerably, and was told that at times they suffered a great deal of pain. I advised them to get abdominal belts for support whilst riding; they did so, and felt great benefit therefrom. On talking the matter over with Mr. E. Huxley, of Old Cavendish-street, he suggested a uterine support, which consists of a peculiar shaped pad with two straps which cross over the sacrum, and are brought to the front and fastened with any amount of tightness the wearer may find desirable. I got him to make one for each of the girls, and they say they are such a comfort and support that they will never ride without them. I think the belt will prove a great blessing to ladies in the hunting field, as well as to professional riders.

R. J. MaItuand CofFin, F.R.C.P. Ed. Baron's Court, S.W., Oct. 188\%.

\section{INTRODUCTORY LECTURE AT YORKSHIRE COLLEGE.}

Dr. Matrhews Duncan commenced by enforcing the importance of the science and practice of virtue. Without virtue they could make but imperfect progress in science, and they must be very imperfect, if not injurious, in practice. If a medical school had not a wholesome moral atmosphere, the teachers would make shabby pupils, and the pupils would grow into mean practitioners. Alluding to the doctrines of evolution, he remarked that that charming and valuable theory had a wide application in biology, and perhaps also in morals ; but it had naturally been forced to extremes by enthusiasts and special pleaders. To such, it would seem, by a kind of flank movement in dialectics, to render vain the great discussions on free will and necessity, and to solve the problem by cramming mankind into a fatalist machine, which dealt with human souls in the same way as pigs were treated in the factories of Chicago. But conscience and responsibility were not to be justly governed by the laws of matter or of life; and the science and practice of virtue were not mere chapters in the theory of evolution. No one doubted the truth of continuity in morals as well as in physics; yet it was necessary to guard against identifying it with evolution. Continuity, a doctrine of the highest importance, implied sequence with connexion, but did not exclude forces which, if they obeyed continuity, were as yet not known, but only suspected to do so. No one doubted the continuity of the prevalence of scarlet fever. It was always among us, carrying off its victims at, at least, an average rate. But that continuity, with its average, was violently disturbednot utterly broken-by the unaccountable appearance of epidemics, which despised the average and raged according to a different law. So, in politics, there was a continuity, but it was disturbed by a Cæosar, a Charlemagne, or a Napoleon. So, in the science of medicine, continuity was modified by a Lavoisier, a Bichat, or a Schwann. So, in the practice of medicine, continuity had its uniformity of course interfered with by a Hippocrates, a Galen, or a Cullen. The appearance of a great original genius in medicine was a matter equally beyond their powers of explanation or control. It appeared to infringe the law of continuity, as that law was known to them by the general progress of professional knowledge. Every sane man, and every sane school, provided according to the known laws of continuity. No sane man conducted his education as that of a great original genius. No wise school provided for other than the average intellect. But this provision, according to the law of continuity, with its averages, did not imply flat sameness, or absence of genius in individuals, or the uselessness of individual effort. Were such perversion of the laws of continuity into the fatalist form of evolution sanctioned, then individual effort, if not utterly useless, would be at least discouraged or paralysed, and his remarks would be baneful and misleading. Medical students had to study the continuity of their individual lives, the continuity of their social lives, as members of a school, and the continuity of their social lives as members of a profession. By individual effort they must push this way and that, always taking care that the direction was to higher and better. They should aim at accumulation of knowledge, acquisition of skill, and improvement in virtue, the last being paramount, and bringing all the rest in its train. Having glanced at the advantages which students now possessed as compared with those obtainable 100 years ago, Dr. Duncan said the amount of knowledge was always increasing, and with it the amount of time needful for its acquirement. Not long ago three years were enough. Now four were required and it looked as if it would soon rise to five. Every medical school should keep the university ideal before it, and this was implied in their Leeds school being now in process of incorporation with a rising university. In the universities of Scotland and Ireland that ideal was maintained. No medical school had a more interesting or more honourable history than that of Leeds -a history that plainly indicated vigorous life, and showed great rapidity of healthy growth. Started in an imperfect form, not much more than balf a century ago, by the wise enthusiasm of a few medical men in the town, it had grown into a completely equipped and recognised medical school, and, already forming part of the Yorkshire College, it would soon, he understood, be completely incorporated with the prosperous Victoria University. They might well be proud of the nursery in which they were reared and passed on to the ranks of the medical profession.

\section{"IS CANCER CONTAGIOUS?" To the Editor of THE LaNCET.}

SIRs,-The interesting question is raised in an annotation in The Lancer of this day as to whether cancer is contagious. M. Duplouy's case certainly gives some grounds for believing that it is so. I daresay it has fallen to the lot of others, more than it has to my own, to observe with regard to this disease equally remarkable "coincidences." And I venture to say that if to such experiences as M. Duplouy's publicity were given, they might prove a means of elucidating valuable facts with regard to this insidious disease. A case of this kind came to my knowledge some time ago, the particulars of which, I think, are worth relating briefly.

A member of the medical profession married a lady who was subsequently found to labour under mammary and uterine cancer, from which she soon died; not long afterwards the gentleman himself, who had previously been healthy, developed symptoms of cancer, which disease subsequently became localised in the stomach and liver. Before his death he again married, and a year or so later the second wife was under the necessity of having both mammæ removed for cancer, in successive operations, and she sank after the second operation.

I am, Sirs, your obedient servant,

Harley-street, W., Oct. 8th, 1887.
JAMES ADAM, MI.D. 